\title{
YOU'RE ON CANDID CAMERA: THE NEED FOR INDIANA TO PRotect Citizens' Rights TO RECORD POLICE
}

\author{
J. MiChael DeWEeSE*
}

"Home of the brave and free, free just to murder me... Is this the new national anthem?"1

\section{INTRODUCTION}

On August 9, 2014, a 911 call is placed at Ferguson Market and Liquor in Ferguson, Missouri, alleging that a strong-arm robbery has occurred. ${ }^{2}$ Less than a mile away, Michael Brown and Dorian Johnson are walking down Canfield Drive, having just left Ferguson Market and Liquor. ${ }^{3}$ Officer Darren Wilson of the Ferguson Police Department was driving down Canfield Drive and encountered Brown and Johnson walking in the middle of the street. ${ }^{4}$ From here, the lack of video evidence of what actually transpired on that day has led to two vastly different accounts of what happened next. ${ }^{5}$

According to witnesses at the scene and Brown's family, Officer Wilson pulled up next to the boys and began yelling at them to get out of the street. ${ }^{6}$ When the boys replied that they were very close to home, Officer Wilson put his car in reverse and nearly hit the boys. ${ }^{7}$ Officer Wilson attempted to get out of his car, but the car door slammed into Brown because of how close the car was to him. ${ }^{8}$ Officer Wilson became angry and grabbed Brown by his neck, pulling him into the window of the police car. ${ }^{9}$ Officer Wilson pulled his gun, threatened to shoot Brown, and subsequently fired a shot that struck Brown somewhere near his chest. ${ }^{10}$ Brown and Johnson began to flee, but they did not make it far before

* J.D. Candidate, 2016, Indiana University Robert H. McKinney School of Law; B.S. 2013, Indiana University Purdue University-Columbus. I would like to thank my family and friends for their continued love, faith, support, and encouragement throughout my life. I would especially like to note a special thanks to Professor Lahny Silva for her critical guidance and motivation throughout the entire Note-writing process.

1. T.I., New National Anthem (Columbia Records 2014).

2. Rachel Clarke \& Christopher Lett, What Happened When Michael Brown Met Officer Darren Wilson, CNN (Nov. 11, 2014, 5:22 PM), http://www.cnn.com/interactive/2014/08/us/ ferguson-brown-timeline/index.html?iid=article_sidebar [http://perma.cc/J3D6-N74J].

3. $I d$.

4. $I d$.

5. Id.; Dueling Narratives in Michael Brown Shooting, CNN (Sept. 16, 2014, 6:19 AM), http://www.cnn.com/2014/08/19/us/ferguson-michael-brown-dueling-narratives/ [http://perma.cc/9HZ6-SHWP] [hereinafter Dueling Narratives].

6. Dueling Narratives, supra note 5.

7. Id.

8. Id.

9. Id.

10. Id. 
Officer Wilson was able to fire a second shot that struck Brown. ${ }^{11}$ Brown turned around to face Officer Wilson with his hands in the air, signaling that he was giving up and no longer a threat. ${ }^{12}$ Officer Wilson disregarded that Brown was surrendering and proceeded to fire more shots until Brown fell face first onto the pavement, dead. ${ }^{13}$

Officer Wilson tells a different story than the above-mentioned account. ${ }^{14}$ Officer Wilson encountered Brown and Johnson walking in the middle of Canfield Drive and when Officer Wilson asked the boys to move out of the street, they became aggressive. ${ }^{15}$ Officer Wilson attempted to get out of his car and Brown slammed the door into Officer Wilson to prevent him from exiting the car. ${ }^{16}$ Brown rushed Officer Wilson, punched him in the face, and began to fight over Officer Wilson's gun. ${ }^{17}$ Two shots went off, which caused Brown to begin to run from Officer Wilson. ${ }^{18}$ Officer Wilson exited his vehicle and pursued Brown until Brown turned around with one fist raised and his other hand in his waistband. ${ }^{19}$ Brown suddenly charged at Officer Wilson, which caused Officer Wilson to fire his gun until Brown dropped dead in front of him. ${ }^{20}$

In the end, Officer Wilson shot and killed Michael Brown. ${ }^{21}$ At least six shots entered Brown's body, with the fatal shot entering through the top of Brown's head. ${ }^{22}$ Citing safety concerns for Officer Wilson and other officers, Officer Wilson subsequently resigned from the Ferguson Police Department. ${ }^{23}$ In the months since Brown's death, Ferguson and other major cities have become an area of unrest and protest. ${ }^{24}$ Police have arrested a number of individuals for protesting and continue to arrest more when the protests get out of control. ${ }^{25}$ The grand jury's decision not to indict Officer Wilson has caused an uproar all across

11. Id.

12. $I d$.

13. $I d$.

14. Ray Sanchez, Darren Wilson Says He's Sorry but His Conscience Is Clear, CNN (Nov. 26, 2014, 7:59 PM), http:/www.cnn.com/2014/11/25/us/darren-wilson-interview/ [http://perma. cc/Z6FD-ZXZF].

15. $I d$.

16. Id.

17. $I d$.

18. Id.

19. Id.

20. Id.

21. Clarke \& Lett, supra note 2.

22. Id.

23. Jack Healy \& Monica Davey, Darren Wilson, Officer in Ferguson Shooting, Resigns from Police Dept., N.Y. Times (Nov. 29, 2014), http://www.nytimes.com/2014/11/30/us/ferguson. html?_r=0 [http://perma.cc/9TDL-L7B9].

24. Ferguson, Mo., Police Shooting, CBS News, http://www.cbsnews.com/fergusonmissouri-police-shooting-protests/ [http://perma.cc/B3NA-Y7X8] (last visited Dec. 22, 2015).

25. Id. 
the United States. ${ }^{26}$ Citizens all across the nation are calling for justice and more evidence that Officer Wilson is indeed an innocent man. ${ }^{27}$ One photograph taken during a protest shows protestors holding signs that call for video evidence of the encounter to be produced. ${ }^{28}$

The major issue with the Michael Brown case is the uncertainty of what actually transpired the day Officer Wilson encountered Brown walking on Canfield Drive. The people of Ferguson and others across the nation are forced to believe either the story favoring Brown or Officer Wilson. Video evidence of what actually happened on that day would put to rest any questions or concerns about police brutality or racially driven motives. Take, for example, the shooting of a twenty-five-year-old black man named Kajieme Powell videotaped on a person's cell phone two weeks after Brown's death. ${ }^{29}$ St. Louis police officers approached Powell after receiving two 911 phone calls identifying him as allegedly stealing from a store and carrying a knife. ${ }^{30}$ St. Louis Police Chief Sam Dotson released a statement that the officers fired on Powell after Powell held his knife in an overhead grip and was three or four feet away from the officers. ${ }^{31}$ Unfortunately for Chief Dotson, the video that was released showed something different. ${ }^{32}$ Powell did approach the police officers, but he was not as close as Chief Dotson stated and his hands were at his side. ${ }^{33}$ Although there was a discrepancy in what Chief Dotson said and what the video showed, the fact that video evidence was released for transparency reasons allowed the citizens to rely on what they could see in the video rather than have to make judgments based off of differing stories. ${ }^{34}$ No disciplinary measures were taken against the officers involved because it was labeled a "lethal situation." 35

This Note advocates for a statute directly allowing citizens to record police officers in the line of duty, which will help safeguard a constitutionally-protected right of citizens, shield cities and police officers from unnecessary lawsuits, and help repair police-citizen relationships. Part I of this Note analyzes the circuit split among federal appellate courts that exists regarding the right to record and how states within the circuits have responded to the court decisions. Part II

26. Andrew Hart, Powerful Photos Show the Nationwide Response to Michael Brown Won't End Any Time Soon, Huffington Post (Nov. 25, 2014, 11:52 PM), http://www.huffingtonpost. com/2014/11/25/ferguson-protests-us_n_6222810.html [http://perma.cc/N6BM-W3HT].

27. $I d$.

28. Id.

29. Ryan Grim \& Ashley Alman, St. Louis Police Release Video of Kajieme Powell Killing that Appears at Odds with Their Story, Huffington Post (Aug. 22, 2014, 5:59 PM), http://www.huffingtonpost.com/2014/08/20/kajieme-powell-shooting_n_5696546.html [http://perma.cc/CT6P-RLCG].

30. Id.

31. Id.

32. $I d$.

33. Id.

34. Id.

35. Id. 
analyzes how the current laws and the lone case in Indiana do not provide adequate protection or guidance on the right to record police-citizen interactions. Part III proposes a new statute for Indiana that will allow citizens to record police activity. The proposed statute sets forth necessary language giving a clear indication that Indiana residents have a right to record. In addition, Part III analyzes consequences and implications of enacting such a statute.

\section{AnAlyzing The CiRcuit Split}

The right to record police activity has been an ongoing issue since average citizens have had the technology to video record from their cell phones ${ }^{36} \mathrm{~W}$ ith so many citizens having the ability to video record police officers in the line of duty, courts have been forced to deal with the legal issues that accompany the ability to record.$^{37}$ Unfortunately, the federal circuits that have dealt with the issue of the right to record have not reached a uniform decision on the extent of that right. ${ }^{38}$ The First, Seventh, and Eleventh Circuits have found that the right to record exists as a right protected by the First Amendment of the U.S. Constitution. ${ }^{39}$ The Third Circuit has not found that the right to record is a clearly established right under the First Amendment ${ }^{40}$ Circuits have approached the right to record in different ways, which has caused a similarly fragmented application at the state level. ${ }^{41}$

\section{A. Eleventh Circuit}

Jason and Barbara Smith owned and operated a small electronics repair shop in Cumming, Georgia in $1995 .{ }^{42}$ One of the Smiths' employees donated sperm to help with the Smiths' attempt to have a child, which angered the employee's girlfriend, Sarah Miles. ${ }^{43}$ Miles proposed a plan to Jason Lingerfelt, a friend, to shoot the Smiths' house while the Smiths were home. ${ }^{44}$ Lingerfelt contacted the Smiths and told them about the plot. ${ }^{45}$ After the Smiths and Lingerfelt filed a

36. Steve Silverman, 7 Rules for Recording Police, Gizmodo (Apr. 10, 2012, 1:00 PM), http://gizmodo.com/5900680/7-rules-for-recording-police [http://perma.cc/P6EE-JARP].

37. $I d$.

38. Id.

39. See Am. Civil Liberties Union v. Alvarez, 679 F.3d 583 (7th Cir. 2012); Glik v. Cunniffe, 655 F.3d 78 (1st Cir. 2011); Smith v. City of Cumming, 212 F.3d 1332 (11th Cir. 2000).

40. See Kelly v. Borough of Carlisle, Nos. 12-4020, 12-4021, 2013 WL 6069275 (3d Cir. Dec. 20, 2013).

41. See e.g., Ken Wallentine, Courts Side with ACLU on Videotaping Police, PoLICEONE. COM (June 11, 2012), https://www.policeone.com/legal/articles/5686435-Courts-side-with-ACLUon-videotaping-police/ [http://perma.cc/35R9-L2YG].

42. Brief for Appellant at 3, Smith v. City of Cumming, 212 F.3d 1332 (11th Cir. 2000) (No. 99-8199).

43. $I d$.

44. Id.

45. Id. at 4 . 
police report, relations between the Smiths and the Cumming Police Department began to deteriorate..$^{46}$ Evidencing the deteriorating relationship between the two, Officer Vince Elsey pulled Barbara Smith over for allegedly "weaving" while driving her car. ${ }^{47}$ Convinced that the police were writing bogus tickets to increase revenue and harass them, Jason Smith began to follow the police, using his police scanner and videotaping their traffic stops ${ }^{48}$ During the tapings, Jason Smith never interfered with the traffic stops, trespassed on private property, or approached the stop close enough to cause any fear or interference with police officers. ${ }^{49}$ Chief of Police Earl Singletary issued an arrest warrant for Jason Smith and the police officers promptly made an appearance at his business to serve the warrant. ${ }^{50}$ The magistrate judge threatened to have Jason Smith thrown in jail without bond if Smith was caught videotaping police activity again. ${ }^{51}$

The Smiths filed suit against the City of Cumming and Chief Singletary, ${ }^{52}$ pursuant to 42 U.S.C. $\S 1983$, which allows citizens of the United States to bring suit against any person that deprives them of any rights, privileges, or immunities that are secured by the U.S. Constitution and laws. ${ }^{53}$ The Smiths alleged that the Cumming Police Department deprived Jason Smith of his First Amendment rights by preventing him from videotaping police actions. ${ }^{54}$ The court granted summary judgment to the City of Cumming and Chief Singletary. ${ }^{55}$ The Smiths appealed to the Eleventh Circuit. ${ }^{56}$ Although the court affirmed the ruling of summary judgment, the Eleventh Circuit discussed the First Amendment right to record police activity. ${ }^{57}$

The court found that the Smiths had a First Amendment right to record the police activity, citing to several other cases where courts allowed public officials to be recorded while carrying out their duties on public property. ${ }^{58}$ Specifically, the court held the First Amendment right applies to gathering information about what public officials do on public property and matters of public interest. ${ }^{59}$ The

\section{Id. at 7 .}

47. Id. at 10 .

48. Id. at 11 .

49. Id.

50. Id.

51. Id. at 12 .

52. Smith, 212 F.3d 1332.

53. 42 U.S.C. $\S 1983$ (2012).

54. Smith, 212 F.3d 1332.

55. Id.

56. Id.

57. Id. at 1333.

58. Id. (citing Iacobucci v. Boulter, No. Civ. A. 94-10531-PBS, 1997 WL 258494 (D. Mass. Mar. 26, 1997); Williamson v. Mills, 65 F.3d 155 (11th Cir. 1995); Fordyce v. City of Seattle, 55 F.3d 436, 439 (9th Cir. 1995); Blackston v. Alabama, 30 F.3d 117, 120 (11th Cir. 1994); United States v. Hastings, 695 F.2d 1278, 1281 (11 th Cir. 1983); Thompson v. City of Clio, 765 F. Supp. 1066, 1070-71 (M.D. Ala. 1991)).

59. $I d$. 
court added this First Amendment right is not absolute, but is subject to reasonable time, manner, and place restrictions. ${ }^{60}$ Even though the Smiths had this constitutional right to record police activity, they failed to carry their burden under section 1983 of proving "that the conduct complained of deprived them of 'a right, privilege or immunity secured by the constitution or laws of the United States." ${ }^{\circ 1}$ As such, it appears that in Eleventh Circuit so long as a person is recording police activity without violating the reasonable time, manner, and place restrictions standard, he or she is protected from arrest.

The Smith decision did not have the effect that those advocating for the right to record had hoped. In fact, there are still citizens arrested for recording police activity in Florida, a state within the Eleventh Circuit. ${ }^{62}$ Those unlawful arrests have been met with penalties for the cities and police officers. ${ }^{63}$ At the end of 2014 , an Orlando man was awarded $\$ 15,000$ in a settlement with the city for being arrested while videotaping a police encounter with another citizen. ${ }^{64}$ In addition, the Orlando Police Department has adopted new policies to deal with the issue of police officers being recorded by citizens while carrying out their duties. ${ }^{65}$ Officers are now directly on notice that they may not order a citizen to stop, or prevent a citizen from, recording them in a public place so long as the citizen is not interfering with officers' duties. ${ }^{66}$ Even though it is an improvement for Orlando to implement policies to protect citizens' right to record, this still does not have the needed power to protect citizens across Florida. Citizens will continue to get arrested in other cities until the Florida Legislature enacts a statute that allows citizens the right to record. Also, those cities where police officers continue to arrest people for exercising their right to record will be subject to substantial settlements that involve thousands of dollars. ${ }^{67}$

\section{B. First Circuit}

On October 1, 2007, Simon Glik, while walking past the Boston Common, observed three police officers arresting a man. ${ }^{68}$ When he overheard another bystander telling the police officers they were hurting the man, he became

60. Id.

61. Id. (quoting Nail v. Cmty. Action Agency of Calhoun Cty., 805 F.2d 1500, 1501 (11th Cir. 1986)).

62. Rene Stutzman, Orlando Pays \$15,000 to Man Who Was Jailed for Video-recording Cops, Orlando Sentinel (Dec. 24, 2014, 12:37 PM), http://www.orlandosentinel.com/news/ breaking-news/os-orlando-pays-man-for-video-recording-arrest-20141224-story.html [http://perma.cc/2S6R-YFNT].

63. Id.

64. Id.

65. Id.

66. Id.

67. See id.

68. Glik v. Cunniffe, 655 F.3d 78, 79 (1st Cir. 2011). 
concerned the police were using excessive force.$^{69}$ Glik stood around ten feet away from the encounter and began to record with his cell phone. ${ }^{70}$ One of the officers noticed that Glik was filming and told Glik that Glik had taken enough pictures. ${ }^{71}$ Glik told the officer he was recording them, which prompted another officer to ask him whether his cell phone recorded audio. ${ }^{72}$ When Glik confirmed that it did, the officer arrested Glik for unlawful audio recording in violation of the Massachusetts's wiretap statute. ${ }^{73}$ The officers then took Glik to the police station, where they confiscated Glik's cell phone and computer flash drive and held them as evidence. ${ }^{74}$

Glik was charged with violation of the wiretap statute, disturbing the peace, and aiding in the escape of a prisoner. ${ }^{75}$ After finding no probable cause to continue the charges against Glik, the City of Boston subsequently dropped all of the charges. ${ }^{76}$ Glik brought a section 1983 claim against the City of Boston and the officers who arrested him, alleging violations of his First and Fourth Amendment rights. ${ }^{77}$ The district court denied the defendants' motion to dismiss, concluding, "in the First Circuit ... this First Amendment right publicly to record the activities of police officers on public business is established." ${ }^{, 78} \mathrm{On}$ appeal, the First Circuit concluded, "Glik was exercising clearly-established First Amendment rights in filming the officers in a public space, and that his clearlyestablished Fourth Amendment rights were violated by his arrest without probable cause." ${ }^{, 79}$ The court cited the Eleventh Circuit in Smith to show that its conclusion on the First Amendment right to record officers in a public space was in accordance with decisions from other circuits. ${ }^{80}$

Here, the First Circuit was in agreement with the Eleventh Circuit that recording government officials, which includes police officers, carrying out their duties in public space fits within the principles of the First Amendment. ${ }^{81}$ The court reiterated the limitations that were stated in Smith v. City of Cumming ${ }^{82}$ to make clear that the right to record is not absolute. ${ }^{83}$ The First Circuit had to consider an additional claim that was not considered in Smith-the Fourth

69. Id. at 79-80.

70. Id. at 80 .

71. Id.

72. Id.

73. Id.

74. $I d$.

75. Id.

76. $I d$.

77. Id.

78. Id.

79. Id. at 79 .

80. Id. at 83 .

81. Id. at 82 .

82. 212 F.3d 1332 (11th Cir. 2000).

83. Glik, 655 F.3d at 84 . 
Amendment claim of arrest without probable cause. ${ }^{84} \mathrm{~W}$ ith regard to the Fourth Amendment determination, the court reasoned that Glik's recording of the officers was not "secret" within the meaning of the wiretap statute, which meant the officers lacked probable cause to arrest him.$^{85}$ This is because Glik was openly filming the officers and the officers were well aware of this open filming. ${ }^{86}$ States within the First Circuit should now recognize the right to record police activity and these states should go one step further in recognizing the violation of Fourth Amendment rights when a person is arrested for lawfully recording police activity.

The Massachusetts Wiretapping Law makes it a crime to record secretly a conversation. ${ }^{87}$ Obtaining consent from one or both of the parties to the conversation eliminates the issue of the recording being in secret. ${ }^{88}$ The First Circuit's decision in Glik makes it clear that if a third-party to the police encounter is recording openly, it is not considered a secret recording. ${ }^{89}$ The issue is that since the case did not directly decide the issue of secretly recording police activity, police officers could still arrest a person for doing so if the officers believe the person is trying to conceal his or her recording device. ${ }^{90}$

In addition to paying Glik $\$ 170,000$ in a settlement for his unlawful arrest, the Boston Police Department issued a training bulletin to its officers about the Massachusetts Wiretapping Law. ${ }^{91}$ The bulletin contains some of the relevant language from the wiretapping law, as well as two cases decided in Massachusetts where the defendant secretly recorded the public officials. ${ }^{92}$ In both of those cases, the citizen recording the encounters purposely recorded the public officials in secret and made no effort to notify the officials that they were being recorded. ${ }^{93}$ The bulletin contained the same clause at the bottom of both pages outlined in bold, "Public and open recordings are allowed under the Wiretap statute. There is no right of arrest for public and open recordings under this statute." ${ }^{94}$ In addition to the bulletin, the Boston Police Department also released a training

84. Id. at 85 .

85. Id. at 88 .

86. Id. at 87 .

87. "The general court further finds that the uncontrolled development and unrestricted use of modern electronic surveillance devices pose grave dangers to the privacy of all citizens of the commonwealth. Therefore, the secret use of such devices by private individuals must be prohibited." MASS. GEN. LAws ch. 272, § 99 (2014).

88. Massachusetts Recording Law, Digital Media L. Project (May 8, 2013), http://www. dmlp.org/legal-guide/massachusetts-recording-law [http://perma.cc/F63G-F759].

89. Id.

90. Andrew, Boston Police Release Training Video on Wiretapping Law, BAY ST. EXAMINER (Apr. 4, 2014), http://baystateexaminer.com/boston-police-release-training-video-wiretapping-law/ [http://perma.cc/7K96-MLST].

91. Id.

92. Id.

93. Id.

94. Id. 
video to its officers that displays two different scenarios of recording to help teach the officers when it is unlawful to record. ${ }^{95}$ The main point to the video is that the recording of the police has to be done secretly for it to be a violation of the wiretapping law. ${ }^{96}$ In a scenario where a person is openly recording the police and not attempting to hide it, this is a lawful recording even if the person does not have the consent of the police to do so. ${ }^{97}$ Although the police in Massachusetts are taking the matters into their own hands with training their officers, there are still numerous reports of people arrested for recording police activity. ${ }^{98} \mathrm{Without}$ a law that expressly allows for citizens to record police activity subject to certain restrictions, the police are forced to determine when a recording is done secretly, resulting in a lack of uniformity within the criminal justice system. ${ }^{99}$ Additionally, those unlawful arrests of citizens exercising their right to record will continue to subject cities in the First Circuit to large settlement amounts like the one Glik received. ${ }^{100}$

\title{
C. Seventh Circuit
}

The American Civil Liberties Union ("ACLU”) was planning to implement a "police accountability program" in the area around Chicago, Illinois. ${ }^{101}$ Specifically, the ACLU wanted to promote police accountability by openly recording police officers without the officers' consent when: (1) the officers were performing their public duties; (2) the officers were in public places; (3) the officers were speaking at a volume audible to the unassisted human ear; and (4) the manner of recording was otherwise lawful. ${ }^{102}$ The ACLU brought suit seeking a declaratory judgment and injunctive relief against the Illinois's State Attorney under section 1983, barring her from enforcing the Illinois eavesdropping statute against them. ${ }^{103}$

The ACLU contended the First Amendment protected its recordings, but was fearful of prosecution. ${ }^{104}$ Accordingly, it sought a declaratory judgment providing that the eavesdropping statute was unconstitutional as applied to its program. ${ }^{105}$ The district court judge held that the ACLU had not alleged a cognizable First Amendment injury because the First Amendment did not recognize the right to record. ${ }^{106}$ On appeal, the Seventh Circuit found there was a First Amendment

\author{
95. Id. \\ 96. Id. \\ 97. Id. \\ 98. Id. \\ 99. Id. \\ 100. See id. \\ 101. Am. Civil Liberties Union v. Alvarez, 679 F.3d 583, 588 (7th Cir. 2011). \\ 102. Id. \\ 103. Id. \\ 104. Id. \\ 105. Id. \\ 106. Id. at 589 .
}


right to gather and disseminate information about government officials performing their duties in public. ${ }^{107}$ Specifically, the Seventh Circuit cited the First Circuit in Glik to show it was in agreement on this First Amendment right to record. ${ }^{108}$ The court also cited the Eleventh Circuit to show that the First Circuit in Glik was aligned with authority from another federal circuit. ${ }^{109}$ Satisfied that the right existed and was in line with other circuits, the court analyzed the eavesdropping statute under heightened First Amendment scrutiny. ${ }^{110}$ The court found that the eavesdropping statute restricted far more modes of communication than were necessary to serve an important government interest. ${ }^{11}$ The court stated, "The Illinois eavesdropping statute restricts an expressive medium used for the preservation and dissemination of information and ideas."112 The court concluded the ACLU had a strong likelihood of success on the merits for its First Amendment claim and remanded the case back to the district court for further proceedings. ${ }^{113}$ After this decision, it would appear states within the Seventh Circuit would recognize the right to record police activity as a constitutionallyprotected right.

In his lengthy dissent, Judge Posner expressed concerns about conversations that take place in public but are intended to be private. ${ }^{114}$ Judge Posner felt the breadth of the right to record could reach certain interactions with police that people would not want broadcasted on the evening news or blogged about on the Internet. $^{115} \mathrm{He}$ specifically mentioned suspects being questioned in an investigation, crime victims seeking police intervention, a person asking for directions, and an injured person seeking help. ${ }^{116}$ Judge Posner stated the right to record would likely impair the police officers' ability to perform their duties and to communicate effectively with citizens. ${ }^{117}$ In his closing thoughts, Judge Posner expressed his concern that although police officers may not have a right to privacy when they are in public performing their duties, citizens do have this right of privacy. ${ }^{118}$ It is true that by allowing citizens to record police activity, they are also recording the citizens that may be involved in the situation. Inevitably, if Indiana passes a statute to allow citizens to record police activity, this issue will need to be discussed and addressed. ${ }^{119}$

Illinois, the Seventh Circuit state involved in American Civil Liberties Union,

107. Id. at 600 .

108. Id.

109. Id. at 614 n. 10 .

110. Id. at 600 .

111. Id. at 606 .

112. Id. at 608 .

113. Id.

114. Id. at 608 (Posner, J., dissenting).

115. Id. at 611.

116. Id.

117. Id.

118. Id. at 613.

119. See infra Part III.C. 
boasted what was one of the nation's toughest and most restrictive eavesdropping laws. $^{120}$ The Illinois Eavesdropping Statute $^{121}$ made it a crime to use an eavesdropping device to record phone calls or conversations unless all parties to the conversation gave consent, regardless of whether there was an expectation of privacy. ${ }^{122}$ The majority in American Civil Liberties Union found that the statute infringed on many constitutionally-protected modes of communication. ${ }^{123}$ The overbreadth of the statute automatically called into question whether it was tailored to an important government interest to withstand scrutiny. ${ }^{124}$

The Illinois Supreme Court sounded the death knell for the overbroad statute with its decision in People v. Melongo. ${ }^{125}$ Annabel Melongo was charged with violating the eavesdropping statute after secretly recording telephone conversations with Cook County court staff. ${ }^{126}$ Melongo challenged the law as unconstitutional under the due process clauses of both the Illinois and U.S. Constitutions. ${ }^{127}$ The Illinois Supreme Court found that the eavesdropping statute deemed all conversations to be private, even when there was no expectation that they would remain private or common sense would signal that they are not private. ${ }^{128}$ The court reasoned the statute criminalized a wide range of innocent conduct and that the statute burdened substantially more speech than was necessary to serve the legitimate government interest necessary for intermediate scrutiny. ${ }^{129}$ The court held, "the recording provision is unconstitutional on its face because a substantial number of its applications violate the first amendment." 130 What can be gleaned from this decision is that courts are now more aware that the right to record government activity, including police officers, is a right protected by the First Amendment. Illinois is a great example of how First Amendment rights are being recognized and protected. Illinois went from one of the strictest eavesdropping statutes to recognizing that it negatively impacted a core First Amendment right.

\section{Third Circuit}

Officer David Rogers pulled over a vehicle for speeding in which Brian Kelly

120. Michael Tarm, Illinois Supreme Court Deals Final Blow to State's Harsh Eavesdropping Law, Huffington Post (Mar. 20, 2014, 6:59 PM), http://www.huffingtonpost.com/2014/ 03/20/illinois-eavesdropping-law_n_5003308.html [http://perma.cc/UML3-VLFA].

121. 720 Ill. Comp. StAT. 5/14-1, 2 (2014).

122. Illinois Recording Law, Digital Media L. Project (Apr. 28, 2014), http://www. dmlp.org/legal-guide/illinois-recording-law [http://perma.cc/X684-4F3F].

123. Am. Civil Liberties Union, 679 F.3d 583 (majority opinion).

124. Id.

125. 6 N.E.3d 120 (Ill. 2014).

126. Id. at 122-23.

127. Id. at 123 .

128. Id. at 126 .

129. Id.

130. Id. 
was a passenger. ${ }^{131}$ Kelly began to record the traffic stop and when Officer Rogers realized Kelly was recording, Officer Rogers seized the camera. ${ }^{132}$ Officer Rogers went back to his patrol car and called the district attorney's office to see if he could arrest Kelly for violating Pennsylvania's wiretapping act. ${ }^{133}$ Based on the advice he received, Officer Rogers arrested Kelly. ${ }^{134}$ The Borough of Carlisle subsequently dropped the charges against Kelly and Kelly filed a section 1983 claim against Officer Rogers and the Borough of Carlisle, alleging violations of his First and Fourth Amendment rights. ${ }^{135}$

The district court granted summary judgment to Officer Rogers and the Borough of Carlisle on both the First and Fourth Amendment claims. ${ }^{136}$ On appeal, the Third Circuit affirmed the summary judgment on the First Amendment claims, but vacated the grant of summary judgment in favor of Officer Rogers on the Fourth Amendment claim. ${ }^{137}$ In analyzing the First Amendment claim, the Third Circuit discussed the Eleventh Circuit's decision in Smith, as well as several other cases that discussed the right to record police activity. ${ }^{138}$ The Third Circuit was unconvinced that these cases clearly established the right to record police activity sufficiently enough to put Officer Rogers on notice that his arrest of Kelly was unlawful. ${ }^{139}$ In particular, two prior decisions within the Third Circuit seemed to imply the U.S. Constitution might not protect videotaping that is done without an expressive purpose. ${ }^{140}$ The Third Circuit was even more unconvinced about the right to record in this situation because none of the prior cases had addressed recording a police officer during a traffic stop, even though there were prior cases that broadly addressed the right to record. ${ }^{141}$

Here, the Third Circuit was left without a clear indication of how to decide this case because no statute existed that allowed Kelly to lawfully record the traffic stop. ${ }^{142}$ The Third Circuit was left to sift through the various cases discussing the right to record police officers and decide if the cases clearly established the right. This is an example of where a statute on the books clearly establishing the right to record would prevent the courts from setting forth limitations on and interpretations of a citizen's constitutionally-protected right to record police activity.

At the same time, it is interesting and unfortunate for states within the Third Circuit that even though the right to record is not "clearly established," cities may

131. Kelly v. Borough of Carlisle, 622 F.3d 248, 251 (3d Cir. 2010).

132. Id.

133. Id.

134. Id. at 252 .

135. Id.

136. Id.

137. Id. at 266 .

138. Id. at 261-62.

139. Id.

140. Id. at 262 .

141. Id.

142. Id. at 260. 
still be subject to paying large settlements for depriving a citizen of this right. ${ }^{143}$ Allen Robinson had a couple of run-ins with the Pennsylvania state troopers when he believed they were conducting truck inspections in an unsafe manner on Route $41 .^{144}$ Robinson began filming the officers conducting their truck inspections while parked on private property on which Robinson obtained permission to be. ${ }^{145}$ After being arrested and charged with harassment when he refused to stop videotaping the police officers, Robinson filed suit under section 1983 for violations of his First Amendment right to free speech and his Fourth Amendment right to be secure against an unreasonable seizure. ${ }^{146}$

The Eastern District of Pennsylvania found that Robinson had a First Amendment right to record the police officers because " $[t]$ he activities of the police, like those of other public officials, are subject to public scrutiny." 147 The court found Robinson was conducting his filming from a safe distance and was not in any way disturbing or interfering with the officers' duties. ${ }^{148}$ The court stated, "Videotaping is a legitimate means of gathering information for public dissemination and can often provide cogent evidence, as it did in this case."149 Having found that Robinson's filming was constitutionally-protected speech, the Eastern District of Pennsylvania found that Robinson's Fourth Amendment rights were also violated when he was arrested for his lawful filming. ${ }^{150}$ The court concluded, "Based upon these facts, no objectively reasonable police officer could have believed that Robinson was committing the offense of harassment under Pennsylvania law."151

Having sided with Robinson on his section 1983 claims, the Eastern District of Pennsylvania moved to the amount of damages Robinson should receive. ${ }^{152}$ The court found, "Robinson is entitled to compensatory damages for any monetary loss, humiliation, and mental anguish caused by the defendants' deprivation of his constitutional rights." ${ }^{53}$ Robinson was required to, and did, prove he suffered damages "as a result of the defendants' violation[] of his rights." ${ }^{154}$ In addition, the court found Robinson was entitled to receive punitive damages for the deprivation of his rights. ${ }^{155}$ The court stated, "Such damages may be awarded in a $\S 1983$ action 'when the defendant's conduct is shown to be motivated by evil motive or intent, or when it involves reckless or callous

143. See Robinson v. Fetterman, 378 F. Supp. 2d 534 (E.D. Penn. 2005).

144. Id. at 538-39.

145. Id. at 539.

146. Id. at 538 .

147. Id. at 541 .

148. Id.

149. Id.

150. Id. at 543 .

151. Id.

152. Id. at 545 .

153. Id.

154. Id.

155. Id. at 546 . 
indifference to the federally protected rights of others." ${ }^{156}$ In the end, the court awarded Robinson $\$ 35,000$ in compensatory damages and $\$ 6000$ in punitive damages for a total of $\$ 41,000 .{ }^{157}$ Therefore, even though this right to record may not be sufficiently established to put an officer on notice, if a district court believes a person's right to record was violated, monetary damages may be assessed against those who prevent the exercise of that right. ${ }^{158}$ Those monetary damages may be compensatory for the deprivation of rights or punitive to punish those who deprived the citizen of his or her rights. ${ }^{159}$

\section{E. Summary}

Citizens' right to record police officers is not adequately recognized or protected, which is evidenced by the existing circuit split in the federal appellate courts. As a result, citizens from different states will receive different results if they have to take their right to record to the courts for a determination. The First, Seventh, and Eleventh Circuits are in agreement that the right to record is protected by the First Amendment of the U.S. Constitution. ${ }^{160}$ Even though the right to record is established in those circuits, there are still barriers created at the state level preventing the right to record from being fully exercised. ${ }^{161}$ Something more needs to be done at the state level to provide citizens with the needed guidance and protection on the right to record police activity. Otherwise, officers will continue to arrest citizens because they misunderstand the right to record, subjecting citizens to a deprivation of their constitutionally-protected right and allowing them to sue cities for large amounts. Similar to other states, the laws and relevant cases in Indiana do not provide enough protection of the right to record.

\section{LACK OF PRotection PROVIDED By INDIANA LAWS}

In Indiana, there are two laws important to the right to record. First, the obstruction of justice statute ${ }^{162}$ will likely be a charge brought against a person who is recording police activity. This was one of the charges brought against Willie King in the lone case from Indiana dealing with the right to record. ${ }^{163}$ Second, the wiretapping statute ${ }^{164}$ does not provide any guidance for the right to record because it only prohibits the interception of electronic communications. ${ }^{165}$

156. Id. at 545 (quoting Smith v. Wade, 461 U.S. 30, 56 (1983)).

157. Id. at 546 .

158. See id.

159. See id. at 545 .

160. See Am. Civil Liberties Union v. Alvarez, 679 F.3d 583 (7th Cir. 2012); Glik v. Cunniffe, 655 F.3d 78 (1st Cir. 2011); Smith v. City of Cumming, 212 F.3d 1332 (11th Cir. 2000).

161. See Stutzman, supra note 62.

162. IND. CODE $\S 35-44.1-2-2$ (2014).

163. King v. City of Indianapolis, 969 F. Supp. 2d 1085, 1089 (S.D. Ind. 2013).

164. "A person who knowingly or intentionally intercepts a communication in violation of this article commits unlawful interception, a Level 5 felony." IND. CODE § 35-33.5-5-5.

165. “'Interception', for purposes of IC 35-33.5, means the intentional recording or acquisition 
The Indiana obstruction of justice statute, wiretapping statute, and the lone Indiana case do not provide citizens with protection from prosecution while they exercise their constitutional right to record police activity.

\section{$A$. King v. City of Indianapolis ${ }^{166}$}

On February 18, 2011, Officer Robert McCauley of the Indianapolis Metropolitan Police Department was involved in a traffic stop with William Gilmore. ${ }^{167}$ Gilmore was intoxicated and began to resist Officer McCauley's attempts to arrest him. ${ }^{168}$ Officer McCauley called for assistance and several other police officers responded to his call for aid. ${ }^{169} \mathrm{~W}$ illie King lived right across the street from where the traffic stop was taking place and stepped out of his home when he heard all of the commotion. ${ }^{170}$ King grabbed his iPhone and began to record the stop as he walked across the street closer to the action. ${ }^{171}$ On King's way, another officer asked King to leave the area, but King responded that he was going to a friend's house as he kept walking toward the police officers. ${ }^{172}$ Once the officers who were engaged in the arrest of Gilmore realized King was recording them, they warned King that if the video showed Gilmore resisting arrest, they could confiscate King's phone. ${ }^{173}$ King continued to record and the police officers demanded King turn his phone over to them. ${ }^{174}$ After refusing to do so, the officers threw King to the ground and arrested him. ${ }^{175}$ The officers also confiscated King's phone, turning it off at the scene. ${ }^{176}$

Officers arrested King for residential entry, obstruction of justice, resisting law enforcement, refusal to leave an emergency incident area, and public intoxication. ${ }^{177}$ Only the charges of resisting law enforcement, disorderly conduct, and public intoxication were actually filed against him, and he was found not guilty of all three at a bench trial. ${ }^{178}$ King brought a section 1983 claim against the City of Indianapolis and his arresting officers, alleging violations of his First and Fourth Amendment rights. ${ }^{179}$ The defendants moved for summary judgment

of the contents of an electronic communication by a person other than a sender or receiver of that communication ....” Id. §35-31.5-2-176.

166. 969 F. Supp. 2d 1085 (S.D. Ind. 2013).

167. Id. at 1088 .

168. Id.

169. Id.

170. Id.

171. Id.

172. Id.

173. $I d$.

174. Id.

175. Id. at 1089.

176. Id.

177. Id.

178. Id.

179. Id. at 1088 . 
on both the First and Fourth Amendment claims. ${ }^{180}$

The court found King's First Amendment right to record police was not clearly established at the time of his arrest. ${ }^{181}$ The court did mention $A C L U^{182}$ as a Seventh Circuit case worthy of discussion, but American Civil Liberties Union was decided after King had been arrested. ${ }^{183}$ King set forth Glik ${ }^{184}$ and Smith ${ }^{185}$ as showing the right to record as a First Amendment right was clearly established. ${ }^{186}$ The defendants set forth Kelly ${ }^{187}$ and another Fourth Circuit case to show the circuit split on the issue. ${ }^{188}$ The court not only agreed the circuit split called into question whether the right to record was clearly established, but was also concerned King's recording in a tense situation where a person was resisting arrest may not satisfy the reasonable time, manner, and place restrictions standard. ${ }^{189}$ The court granted the defendants summary judgment on the First Amendment claim. ${ }^{190}$

On the Fourth Amendment claim, King contended the seizure of his phone was not justified by exigent circumstances that would make it law ful. ${ }^{191}$ The court held there was a "clearly established right to be free from the warrantless seizure of a cell phone." 192 The court explained the right was especially clear here "where $\mathrm{Mr}$. King was video recording police activity and crime, but was not himself engaged in unlawful activity at the time the iPhone was seized." ${ }^{193}$ The court next examined whether the exigent circumstances justified police action and the need to conduct a warrantless search and seizure. ${ }^{194}$ Here, the compelling need would have been to prevent the destruction of evidence since King was filming Gilmore resisting arrest. ${ }^{195}$ The court was unconvinced King posed such a risk to the police officers to justify their warrantless search and seizure of King's cell phone. ${ }^{196}$ The court was not convinced an officer would feel the evidence on the phone was necessary or that he or she could not obtain a warrant to retrieve the video. ${ }^{197}$ Therefore, the court denied summary judgment on the Fourth Amendment

180. Id.

181. Id. at 1090 .

182. Am. Civil Liberties Union v. Alvarez, 679 F.3d 583 (7th Cir. 2012).

183. King, 969 F. Supp. 2d at 1090.

184. Glik v. Cunniffe, 655 F.3d 78 (1st Cir. 2011).

185. Smith v. City of Cumming, 212 F.3d 1332 (11th Cir. 2000).

186. King, 969 F. Supp. 2d at 1090-91.

187. Kelly v. Borough of Carlisle, 622 F.3d 248 (3d Cir. 2010).

188. King, 969 F. Supp. 2d at 1091.

189. Id. at 1092.

190. Id.

191. $I d$.

192. Id.

193. Id. at 1093 .

194. Id.

195. Id.

196. Id.

197. Id. 
claim. ${ }^{198}$

King illustrates how the inconsistencies surrounding the right to record may affect a court. Here, the court was unable to utilize American Civil Liberties Union in the Seventh Circuit because it had not been decided prior to King's arrest. ${ }^{199}$ The court was forced to weigh the cases from other federal circuits and, due to the circuit split, was unconvinced the right to record was clearly established..$^{200}$ It would be interesting to see if an Indiana court dealing with the right to record now would find the right to be clearly established based on American Civil Liberties Union. The better approach would be to have the Indiana General Assembly clarify the right with a statute, taking the issue out of the courts' hands. This would provide courts with a clear standard to use in deciding cases regarding the right to record police activity. The court in King called into question whether the seizure of a person's cell phone would be warranted when a person is recording police activity. ${ }^{201}$ This is important because it tends to show the court at least recognized the recording of police activity in isolation is not criminal enough to reach the level of requiring a warrantless search and seizure. ${ }^{202}$

When the case came to a close, the City of Indianapolis reached deep into its pockets to compensate King for being unlawfully arrested. ${ }^{203}$ The court awarded King \$200,000 in a settlement and instructed Indianapolis to remind its officers that citizens are legally entitled to videotape officers while officers are on-duty. ${ }^{204}$ The relatively large sum of money the court required Indianapolis to pay King would appear to be a good indication that constitutionally-protected rights are taken very seriously by courts. Other cities should look at this large settlement as an incentive to ensure they are not depriving citizens of their protected rights.

The policy Indianapolis adopted for the police officers states officers should not interfere with citizens recording officers' actions in public so long as the recording does not pose any significant risk to the officer or individuals involved in the encounter. ${ }^{205}$ Although this policy is an improvement in the way of the right to record police activity, it still only helps citizens that film officers in Indianapolis. Citizens in other cities across the state will still be subject to a deprivation of their right to record if the police officers in that city are not put on notice of this right. This is where the Indiana General Assembly can step in and limit any further litigation on the right to record police activity. Currently, the two relevant statutes provide a complete lack of guidance on dealing with the right to

198. Id.

199. Id. at 1090 .

200. Id. at 1092 .

201. Id. at 1093 .

202. Id.

203. Indianapolis Cops Must Allow Citizens to Film Police Activity After $\$ 200 k$ Settlement, RT(Feb. 24, 2014, 7:18 PM), http://rt.com/usa/indianapolis-settlement-record-police-254/ [http:// perma.cc/95AC-RL85] [hereinafter Indianapolis Cops].

204. Id.

205. Id. 
record.

\section{B. Indiana's Obstruction of Justice Statute 206}

Obstruction of justice was one of the crimes for which King was arrested but not formally charged. ${ }^{207}$ The charge was likely brought against King under Indiana Code section 35-44.1-2-2(a)(3) as a "person who alters, damages, or removes any record, document, or thing, with intent to prevent it from being produced or used as evidence in any official proceeding or investigation." ${ }^{208}$ It is not surprising prosecutors did not formally charge this crime against King. The problem with applying this statute to recording police activity deals with the issue of intent. ${ }^{209}$ The person recording police activity is not intending to withhold the video as evidence. ${ }^{210}$ The person's intent is to exercise his or her First Amendment right to record government activity and to disseminate that information to the public. The issue is that police officers, at the time of being recorded, need to be aware of this right to record or people will continue to get arrested and charged with obstruction of justice when they record and refuse to turn over the phone. ${ }^{211}$ A statute allowing for the recording of police activity would provide sufficient notice to the police officers that a citizen recording officers' activity in a public place is lawful.

\section{Indiana Wiretapping Statute ${ }^{212}$}

Indiana only prohibits the interception of an electronic communication. ${ }^{213}$ Cases that have been brought pursuant to the wiretapping statute deal with the taping of telephone conversations, not in-person conversations. ${ }^{214}$ This will not pose a problem for citizens who are recording their own or others' interactions with police in-person. King was not charged with violating the wiretapping

206. IND. CODE § 35-44.1-2-2 (2014).

207. King, 969 F. Supp. 2d at 1089.

208. IND. CODE $\S 35-44 \cdot 1-2-2(a)(3)$.

209. Id. §35-44.1-2-2.

210. Id.

211. King, 969 F. Supp. 2d at 1089.

212. See generally IND. CODE $\S \S 35-33.5-2-1$ to $-5-6$.

213. “'Electronic communication', for purpose purposes of IC 35-33.5, means any transfer of signs, signals, writing, images, sounds, data, oral communication, digital information, or intelligence of any nature transmitted in whole or in part by a wire, a radio, or an electromagnetic, a photoelectronic, or a photo-optical system.” Id. § 35-31.5-2-110.

214. See Steinberg v. State, 941 N.E.2d 515 (Ind. Ct. App. 2011) (involving tape recordings of collect phone calls to a defendant's parents made from jail); Packer v. State, 800 N.E.2d 574 (Ind. Ct. App. 2003) (involving recorded telephone calls from jail between a defendant and his girlfriend); Apter v. Ross, 781 N.E.2d 744 (Ind. Ct. App. 2003) (involving recorded phone conversation between a defendant's ex-wife and child); State v. Lombardo, 738 N.E.2d 653 (Ind. 2000) (involving tape recording of an estranged wife's telephone conversations). 
statute. ${ }^{215}$ This is not surprising because King was recording the events in-person in his neighbor's yard. ${ }^{216}$ In any event, it is highly unlikely that a citizen recording a police encounter in-person will do so in a manner that would violate the wiretapping statute. Therefore, the Indiana Wiretapping Statute provides absolutely no guidance or insight into the right to record in-person police encounters.

Indiana lacks current statutory provisions and case law to protect the right to record police activity adequately. ${ }^{217}$ Indiana needs express statutory language allowing citizens to record police activity and be free from unlawful arrest for exercising that right.

\section{INDIANA's NEW STATUTE}

The Indiana General Assembly has an opportunity to provide the citizens of the state with a statute that reinforces the right to record police and provides that right with protection. Utilizing the decisions from the federal circuits, the legislators have been given an ideal blueprint on how to formulate the statute. However, like any new legislation, there will be implications that will need to be addressed and discussed with the passing of this statute.

\section{A. Necessary Language}

First, building off of the decisions from the First, Seventh, and Eleventh Circuits, the new statute needs to state that the right to record public officials is a right that is protected by the First Amendment of the U.S. Constitution. ${ }^{218}$ This will impress upon citizens the importance and superiority of this right. The First Circuit in Glik quoted language from the U.S. Supreme Court about the right to gather information regarding government officials: "Gathering information about government officials in a form that can readily be disseminated to others serves a cardinal First Amendment interest in protecting and promoting 'the free discussion of governmental affairs." ${ }^{219}$ The statute could lay forth this exact language from the U.S. Supreme Court to provide the foundation and authority for such a statute.

Next, the statute absolutely must contain language that law enforcement officials are expected to respect the right to record and provide protection of that right. This was the major issue that the Third Circuit struggled with in Kelly. ${ }^{220}$ The Third Circuit did not believe the cases dealing with the right to record clearly established the right in a manner that would put Officer Rogers on notice that the

215. King, 969 F. Supp. 2d at 1089.

216. Id. at 1088 .

217. See id. at 1085; IND. CoDE $\S \S 35-44.1-2-2,-31.5-2-176$.

218. See Am. Civil Liberties Union v. Alvarez, 679 F.3d 583 (7th Cir. 2011); Glik v. Cunniffe, 655 F.3d 78 (1st Cir. 2011); Smith v. City of Cumming, 212 F.3d 1332 (11th Cir. 2000).

219. Glik, 655 F.3d at 82 (quoting Mills v. Alabama, 384 U.S. 214, 218 (1966)).

220. Kelly v. Borough of Carlisle, 622 F.3d 248, 262 (3d Cir. 2010). 
right existed. ${ }^{221}$ By placing in the statute clear and express language that law enforcement officials are to respect and protect the right to record, Indiana will alleviate burden courts face in having to determine if the right was clearly established.

\section{B. Important Limitations on the Right to Record}

There are important limitations that must be placed on the right to record public officials. First, there must be language that the recording must be done while the government official is carrying out his or her duties in a public space. All three circuits that have found the right to record have been careful to place in language that this right to record exists while the government official is carrying out his or her duties in public. ${ }^{222}$ The Seventh Circuit in American Civil Liberties Union quoted language from the U.S. Supreme Court about communications by government officials in public: "Communications of this sort lack any "reasonable expectation of privacy' for purposes of the Fourth Amendment." ${ }^{223}$ The court also used this language from the Supreme Court: "[C]onversations in the open would not be protected against being overheard, for the expectation of privacy under the circumstances would be unreasonable." ${ }^{224}$ By specifically providing for the right to record government officials in a public space only, Indiana will eliminate concerns of "secret" or "private" recordings that caused problems in Massachusetts. ${ }^{225}$

Second, the statute must contain the restriction of reasonable time, manner, and place. The Eleventh Circuit set forth this limitation in Smith. ${ }^{226}$ The First and Seventh Circuit also discussed this limitation in regard to the boundaries of the right to record. ${ }^{227}$ The First Circuit was the only one to discuss any further the restriction in its decision by stating, "Such peaceful recording of an arrest in a public space that does not interfere with the police officers' performance of their duties is not reasonably subject to limitation." ${ }^{228}$ Therefore, it appears from the First Circuit's language that safety, interference with police performance, and distance would be relevant factors to consider in the limitation. Placing this limitation on the right to record will leave some discretion to police officers involved in the recorded encounter, as well as to the courts that may have to

221. Id.

222. See Am. Civil Liberties Union, 679 F.3d 583; Glik, 655 F.3d 78; Smith, 212 F.3d 1332.

223. Am. Civil Liberties Union, 679 F.3d at 606 (citing Katz v. United States, 389 U.S. 347, 351 (1967)).

224. Id. (quoting Katz, 389 U.S. at 361 (Harlan, J., concurring)).

225. Andrew, supra note 90.

226. See Smith, 212 F.3d at 1333 ("[T] reasonable time, manner and place restrictions, to photograph or videotape police conduct.").

227. See Am. Civil Liberties Union, 679 F.3d at 605; Glik, 655 F.3d at 84 ("To be sure, the right to film is not without limitation. It may be subject to reasonable time, place, and manner restrictions.").

228. Glik, 655 F.3d at 84 . 
adjudicate claims regarding the right to record. Discretion for the police officers is important because their lives can be in danger during certain situations. Some guiding examples of this limitation come from the policy that Indianapolis was to adopt after the settlement it made with Willie King. ${ }^{229}$ There needs to be a safe and reasonable distance between the civilians recording and the police officers involved in the encounter. ${ }^{230}$ Civilians recording the police encounter should not in any way interfere with police officers' duties or performance. ${ }^{231}$ Lastly, civilians recording the encounter should not pose a physical danger to the officers involved or others at the scene. ${ }^{232}$ Therefore, it would appear the polestar of this limitation is safety for the officers and anyone else involved in the encounter.

Because of this concern for safety, there should also be within the statute a provision that expressly allows police officers to levy punishment against a citizen recorder who has refused to comply with a reasonable instruction to move away from an encounter. During the heat of the moment, police officers will be best able to determine when citizens who are recording an encounter could possibly be in danger or endanger others. Police officers need the ability to take control of the situation and restore calm to the area.

\section{Implications and Consequences of the Statute}

Judge Posner's dissent in American Civil Liberties Union raised a few important issues that need to be addressed in regard to the right to record. ${ }^{233}$ First, Judge Posner expressed a concern for the safety of police officers. ${ }^{234}$ Judge Posner was fearful that citizens recording their conversations will distract police officers or that police officers will always be on the lookout for any device that could be recording them. ${ }^{235}$ Specifically, Judge Posner stated, "To distract police during tense encounters with citizens endangers public safety and undermines effective law enforcement." ${ }^{236}$ Although it is true that citizens recording police officers may cause a distraction, the statute proposed contains language that places limitations on the right to record and gives police discretion on moving people away from the area, alleviating some of those concerns. ${ }^{237}$ Also, to continue to deprive citizens of the right to record because there is a concern for police being distracted will continue to subject cities to large settlements when citizens sue. ${ }^{238}$ Indiana's new statute will effectively balance these two concerns

229. Indianapolis Cops, supra note 203.

230. Id.

231. Id.

232. Id.

233. Am. Civil Liberties Union v. Alvarez, 679 F.3d 583, 608 (7th Cir. 2011) (Posner, J., dissenting).

234. Id. at 611-12.

235. Id.

236. Id. at 612 .

237. See supra Part II (discussing the limitations on the Indiana statute).

238. See Stutzman, supra note 62; see Indianapolis Cops, supra note 203. 
and still allow police officers the ability to take control of a situation when safety becomes a legitimate concern. ${ }^{239}$

Next, Judge Posner expressed a concern that allowing citizens to record police will hinder them from effectively doing their job. ${ }^{240}$ Judge Posner believed that victims and informants will be reluctant to approach police officers in public because of the concern of being recorded. ${ }^{241}$ Judge Posner did not feel it is feasible to always expect these individuals to take their conversations to a police station to avoid being overheard and recorded. ${ }^{242}$ He stated, "[T]he people who most need police assistance and who most want their conversations kept private are often the people least able to delay their conversation until they reach a private place. ${ }^{243}$ Judge Posner pointed out some very personal crimes that would be difficult for a person to wait to tell the details, like rapes and muggings. ${ }^{244}$ Although Judge Posner's concerns are legitimate, society is currently dealing with a rapidly deteriorating relationship between police and citizens. ${ }^{245}$ Indiana has to decide how best to deal with this deteriorating relationship and lack of trust for police. By allowing people to hold police officers accountable, citizens will likely feel as though they have more control and satisfaction with police work. Additionally, Judge Posner assumed citizens will randomly walk up to police officers and begin filming for seemingly no reason. ${ }^{246}$ However, there is enough evidence that people have specific reasons for why they want to film police officers and do not just do it randomly. ${ }^{247}$

Lastly, Judge Posner expressed a concern for the privacy of citizens involved in the recordings. ${ }^{248} \mathrm{He}$ stated, "Police may have no right to privacy in carrying out official duties in public. But the civilians they interact with do." ${ }^{249}$ Judge Posner talked about conversations that are had in public, but are intended to be private and personal. ${ }^{250}$ People do not usually bother to eavesdrop on these conversations because they would only hear a piece of the conversation out of context and it would not make sense. ${ }^{251}$ Judge Posner was concerned that by allowing these private conversations of citizens to be recorded and plastered on

239. See supra Part II (discussing the limitations on the Indiana statute).

240. Am. Civil Liberties Union, 679 F.3d at 614 (Posner, J., dissenting).

241. Id.

242. $I d$.

243. Id.

244. Id.

245. See Ferguson, Mo., Police Shooting, supra note 24; see Hart, supra note 26.

246. Am. Civil Liberties Union, 679 F.3d at 613 (Posner, J., dissenting).

247. See id. at 583 (majority opinion); Glik v. Cunniffe, 655 F.3d 78 (1st Cir. 2011); Kelly v. Borough of Carlisle, 622 F.3d 248 (3d Cir. 2010); Smith v. City of Cumming, 212 F.3d 1332 (11th Cir. 2000); King v. City of Indianapolis, 969 F. Supp. 2d 1085 (S.D. Ind. 2013).

248. Am. Civil Liberties Union, 679 F.3d at 613 (Posner, J., dissenting).

249. $I d$.

250. $I d$.

251. Id. at 614 . 
the Internet, a citizen's right to privacy is breached. ${ }^{252}$ The counter to Judge Posner's privacy concerns for citizens is something that he references himself in his dissent- the competing balance of First Amendment rights. ${ }^{253}$ Although citizens may enjoy a right to privacy, the First Amendment right to gather and disseminate information about public officials discussed by the First Circuit in Glik may well trump this right to privacy. ${ }^{254}$

Indiana must balance the competing First Amendment rights with the right to privacy. The statute would expressly allow recording of government officials carrying out their duty in a public space. A citizen's right to privacy will still be respected to the fullest extent without trampling on the competing First Amendment right of citizens to gather and disseminate information about government affairs.

Therefore, Judge Posner did set forth important and legitimate concerns that will accompany the right to record. ${ }^{255}$ These concerns are ones that the Indiana General Assembly will have to address in passing a statute. Competing interests will also require analysis and consideration. However, the correct direction for Indiana will be to pass this statute and provide citizens with the express constitutional right that they deserve.

\section{CONCLUSION}

The right to record government officials carrying out their duties in public is a right protected by the First Amendment of the U.S. Constitution. Currently in Indiana, that right is not given the full and deserved protection it needs. The citizens of Indiana are currently hindered in their ability to gather and disseminate information about government. The Indiana General Assembly needs to step up and pass a statute that will alleviate any further concerns regarding the right to record.

The new statute will help to conserve judicial resources and limit further litigation on the matter. With more citizens possessing the capability to record from anywhere, the right to record will be exercised more frequently. As has been illustrated, cities within Indiana will become subject to large settlements with citizens who sue because their right to record has been violated by a police officer. Indiana has the ability to stop this from happening again by passing a new statute that allows citizens to record and putting police officers on notice.

Without such a statute, Indiana will allow further deterioration in the trust between citizens and police officers. This is perhaps the most important reason for the passing of the statute. Police officers are supposed to be individuals that citizens can trust to protect them and serve the interests of the public. After the events in Ferguson, Missouri, relations between police and citizens have been steadily deteriorating. Citizens feel a lack of control and argue that police officers

252. Id. at 613 .

253. Id.

254. Glik v. Cunniffe, 655 F.3d 78, 82 (1st Cir. 2011).

255. Am. Civil Liberties Union, 679 F.3d at 608 (Posner, J., dissenting). 
are not held accountable for their actions. Indiana can put power back into the hands of the citizens by protecting their right to record police officers in the line of duty and hold them accountable to the people. With this ability to oversee police, undoubtedly citizens will feel that they have more control and impact on how police officers act. There is no better time than the present for Indiana to make its move to provide its citizens with the right to record. 